\title{
APC hypermethylation for early diagnosis of colorectal cancer: a meta-analysis and literature review
}

\author{
Tie-Jun Liang ${ }^{1}$, Hong-Xu Wang ${ }^{2}$, Yan-Yan Zheng ${ }^{3}$, Ying-Qing Cao ${ }^{4}$, Xiaoyu Wu ${ }^{5}$, Xin \\ Zhou ${ }^{6}$ and Shu-Xiao Dong ${ }^{7}$ \\ ${ }^{1}$ Department of Digestive Disease, Shandong Provincial Hospital Affiliated to Shandong University, Jinan, Shandong, China \\ ${ }^{2}$ Department of General Surgery, Jiyang People's Hospital, Jiyang, Shandong, China \\ ${ }^{3}$ Department of Medical Imaging, Jiyang People's Hospital, Jiyang, Shandong, China \\ ${ }^{4}$ Department of Anus \& Intestine Surgery, Taian City Central Hospital, Taian, Shandong, China \\ ${ }^{5}$ Department of Surgical Oncology, The Affiliated Hospital of Nanjing Medical University, Nanjing, Jiangsu, China \\ ${ }^{6}$ Department of General Surgery, Jiangsu Cancer Hospital, The Affiliated Cancer Hospital of Nanjing Medical University, \\ Nanjing, Jiangsu, China \\ ${ }^{7}$ Department of Gastrointestinal Surgery, Linyi People's Hospital, Linyi, Shandong, China \\ Correspondence to: Shu-Xiao Dong, email: shuxiaodong76@outlook.com
}

Keywords: adenomatous polyposis coli, APC, methylation, biomarker, adenoma

Received: September 12, $2016 \quad$ Accepted: April 02, $2017 \quad$ Published: May 02, 2017

Copyright: Liang et al. This is an open-access article distributed under the terms of the Creative Commons Attribution License 3.0 (CC BY 3.0), which permits unrestricted use, distribution, and reproduction in any medium, provided the original author and source are credited.

\section{ABSTRACT}

Adenomatous polyposis coli (APC) promoter hypermethylation has been frequently observed in colorectal cancer (CRC). The association between APC promoter methylation and clinicopathological significance in CRC is under investigation. We performed a meta-analysis to quantitatively evaluate the significance of APC methylation in CRC. The study included a total of 24 articles and 2025 CRC patients. The frequency of $A P C$ promoter hypermethylation was significantly higher in colorectal adenoma than in normal colorectal tissue, OR was 5.76, 95\% CI, 2.45-13.56; $\mathrm{p}<0.0001, I^{2}=0 \%$. $A P C$ promoter more frequently hypermethylated in CRC stage I compared to normal colorectal tissue, OR was $13.42,95 \% \mathrm{CI}, 3.66-49.20 ; \mathrm{p}<0.0001, I^{2}=31 \%$. The risk of incidence of CRC was significantly correlated to APC promoter hypermethylation, pooled OR was $9.80,95 \% C I, 6.07-15.81 ; p<0.00001, I^{2}=43 \%$. APC methylation was not associated with grade, stage of CRC as well as tumor location, patients' gender, and smoking behavior. The results indicate that $A P C$ promoter hypermethylation is an early event in carcinogenesis of $\mathrm{CRC}$, could be a valuable diagnostic marker for early-stage CRC. APC methylation is not significantly associated with overall survival in patients with CRC. APC is a potential drug target for development of personalized treatment.

\section{INTRODUCTION}

Colorectal cancer (CRC) is one of the most common types of cancer worldwide and results from the accumulation of genetic and epigenetic alterations in colonic mucosa cells, which ultimately leads to colorectal adenoma, advanced to invasive and metastatic CRC. Unfortunately, the prognosis of CRC in late stages is still poor and the search of novel diagnostic and prognostic biomarkers is highly desired to prevent CRC-related mortality. During last decade, epigenetic alterations have been reported to play an important role in many cancers initiation, progression, and metastasis [1,2]. DNA methylation within $\mathrm{CpG}$ island in promoter region of genes is associated with the loss of gene expression and is observed in many types of cancers including CRC. Adenomatous polyposis coli $(A P C)$, a suppressor gene, is located at chromosomal band 5q21-q22 and consists of 15 exons. $A P C$ was discovered by genetic linkage analysis in familial adenomatous polyposis (FAP) and was reported by Kinzler [3], Nishisho [4], Joslyn 
[5] and Groden [6]. Recently APC is thought of as a negative regulator in Wnt/beta-catenin signaling pathway. Loss of APC function leads to the destabilization and degradation of betacatenin, and the nuclear accumulation of beta-catenin results in the activation of T-cell factor/LEF target gene and initiates tumorgenesis [7, 8]. APC along with several other inactivated genes plays a prognostic indicatory role in squamous cell and adenocarcinoma of esophagus, bladder and lung cancers [9]. In the past two decades, $A P C$ promoter hypermethylation was frequently observed in sporadic and familial CRC. However, the association between clinicopathological significance and $A P C$ methylation was under investigated. The present article aims to summarize the most recent findings concerning the use of epigenetic (mainly related to DNA methylation) biomarkers for CRC diagnosis, progression, and response to treatment.

\section{RESULTS}

\section{Identification of relevant studies}

36 publications were identified by the search method as described above. Eleven of those were excluded due to laboratory studies, non-original articles (review), or studies irrelevant to the current analysis. Eventually, there were 24 studies included in the final meta-analysis as shown in Figure 1.

\section{Study characteristics}

24 studies published from 2004 to 2015 were eligible for meta-analysis. A total of 1396 samples including CRC, colorectal adenoma and normal control tissues from Greece, Iran, Sweden, Vietnam, China, South Korea, Japan, UK, Kashmir, Czech Republic, Australia, Netherland, Germany, Norway, and USA were included in the analysis. Their basic characteristics are summarized in Table 1.

\section{The correlation of $A P C$ hypermethylation with clinicopathological features}

1. The inactivation of $A P C$ through promoter hypermethylation in adenoma and CRC.

$A P C$ promoter hypermethylation was an early event in carcinogenesis. The frequency of $A P C$ promoter hypermethylation was significantly increased in adenoma than in normal colorectal tissues, OR was $5.76,95 \% \mathrm{CI}, 2.45-13.56$; $\mathrm{p}<0.0001$, $I^{2}=0 \%$ (Figure 2). $A P C$ promoter was more frequently hypermethylated in CRC stage I than normal colorectal tissue, OR was 13.42, 95\% CI, 3.66-49.20; $\mathrm{p}<0.0001, I^{2}=31 \%$ (Figure 3 ). The risk of incidence of CRC was significantly correlated to $A P C$ promoter hypermethylation, pooled OR was 9.80, 95\%CI, $6.07-15.81 ; \mathrm{p}<0.00001, I^{2}=43 \%$ (Figure 4).

2. $A P C$ promoter hypermethylation was not associated with grade and stage of CRC.
The frequency of $A P C$ promoter hypermethylation was similar between low and high grade of CRC, pooled OR was $1.01,95 \% \mathrm{CI}, 039-2.61$; $\mathrm{p}=0.99, I^{2}=81 \%$ (Figure 5). There was no difference when comparing the frequency of $A P C$ promoter hypermethylation between $\mathrm{I} /$ II stage and III/IV stage of CRC, pooled OR was 0.85 , $95 \%$ CI, $0.63-1.15 ; \mathrm{p}=0.29, I^{2}=0 \%$ (Figure 6).

3. There was no statistically significant association between $A P C$ methylation status and other clinical parameters, including tumor location, gender and smoking status of CRC patients.

Proximal versus distal: OR was $0.87,95 \% \mathrm{CI}, 0.67-$ $1.13, \mathrm{p}=0.31, I^{2}=0 \%$ (Figure 7).

Male versus female: OR was $1.55,95 \% \mathrm{CI}, 0.88$ $1.52, \mathrm{p}=0.31, I^{2}=0 \%$ (Figure 8 ).

Smoker versus non-smoker: OR was $1.63,95 \% \mathrm{CI}$, 0.88-2.99, $\mathrm{p}=0.12, I^{2}=0 \%$ (Figure 9).

4. Overall survival was analyzed by selecting Colorectal Adenocarcinoma (TCGA, Nature 2012) [10] and gene $A P C$ via cBioPortal for provisional data. The survival curve was plotted on 236 cases (methylation HM27) which included 72 cases with $A P C$ hypermethylation (methylation beta-value was more than 0.3) and 164 cases with $A P C$ low methylation (methylation beta-value was more than 0.3). T-test p-value was 0.5798 , indicating $A P C$ methylation was not significantly associated with overall survival in patients with CRC (Figure 10).

\section{Sensitivity analyses and publication bias}

To minimize the effect of confounders, a sensitivity analysis, in which one study was removed at a time, was conducted to assess the result stability. The pooled ORs were not significantly changed, indicating the stability of our analyses. The funnel plots demonstrates no obvious asymmetry (Figure $11 \mathrm{~A}-11 \mathrm{H}$ ), suggesting the absence of publication biases in the meta-analysis of $A P C$ hypermethylation and clinicopathological features.

\section{DISCUSSION}

CRC is thought to develop from adenomatous polyps following the accumulation of mutations which includes the activation of oncogenes and the inactivation of tumor suppressor genes [11-15]. Tumor suppressor genes associated with CRC include $A P C, p 53, B R A F$ and $D C C[10,15]$, and the loss of APC has been observed in approximately $70-80 \%$ of CRC [16-19], but the association between $A P C$ promoter methylation and clinicopathological significance in CRC is unclear. The current study systematically reviewed all published evidence before July 2016 and synthesized data from three studies and 196 adenoma samples using a metaanalysis. Our result indicated that the $A P C$ promoter is 5.76 times more frequently hypermethylated in adenoma 
than in normal colorectal tissue. In addition, the frequency of $A P C$ hypermethylation in CRC stage I was 13.42 times higher than in normal colorectal tissue. Patients with early-stage CRC could expect a long survival with surgery alone, but about 50\% stage III and 25\% stage II will relapse and need adjuvant chemotherapy [20]. Therefore, $A P C$ hypermethylation as a valuable early diagnostic marker could contribute to making the decision whether or not to accomplish chemotherapy. Ding et al published a meta-analysis of the association between $A P C$ promoter methylation and colorectal cancer, in which the $A P C$ promoter hypermethylation has not been analyzed in early-stage CRC.

We pooled 12 studies and included 762 CRC samples and 343 normal colorectal tissues, and the data demonstrated the frequency of $A P C$ hypermethylation in CRC was 9.8 times higher than in normal colorectal tissues; the heterogeneity was $43 \%$. We removed three studies that caused higher heterogeneity (the heterogeneity was $83 \%$, OR was $4.35,95 \%$ CI was $1.56-12.12)$. One of the three studies (Xu et al.) reported low frequency of $A P C$ methylation in CRC (7.7\%) compared to other studies ( $A P C$ methylation rate arranged from $17.9 \%$ to $62.8 \%$ ), two studies (Dimberg at al. and Michailidi et al.) reported high rate of $A P C$ methylation $(65.3 \%$ and $85.7 \%)$ in normal colorectal tissues compared to other studies ( $A P C$ methylation rate arranged $0-25 \%$ ). The frequency of $A P C$ hypermethylation was similar between CRC and adenoma (data not shown), this result is consistent with previous study [21]. Our results suggest that $A P C$ promoter hypermethylation is an early event during colorectal carcinogenesis. Previous evidence suggest that $A P C$ methylation is not a "second hit" in two hit model of $A P C$ mutation in tumor [22]. This explains why $A P C$ promoter hypermethylation was an early event during the development of CRC. As the changes in $A P C$ promoter hypermethylation are reversible, demethylation with drug could delay carcinogenesis and progression of CRC. Previous studies showed that adenoma formation in $A P C \mathrm{~min} /+$ was inhibited by 5 -aza-deoxycitidine,

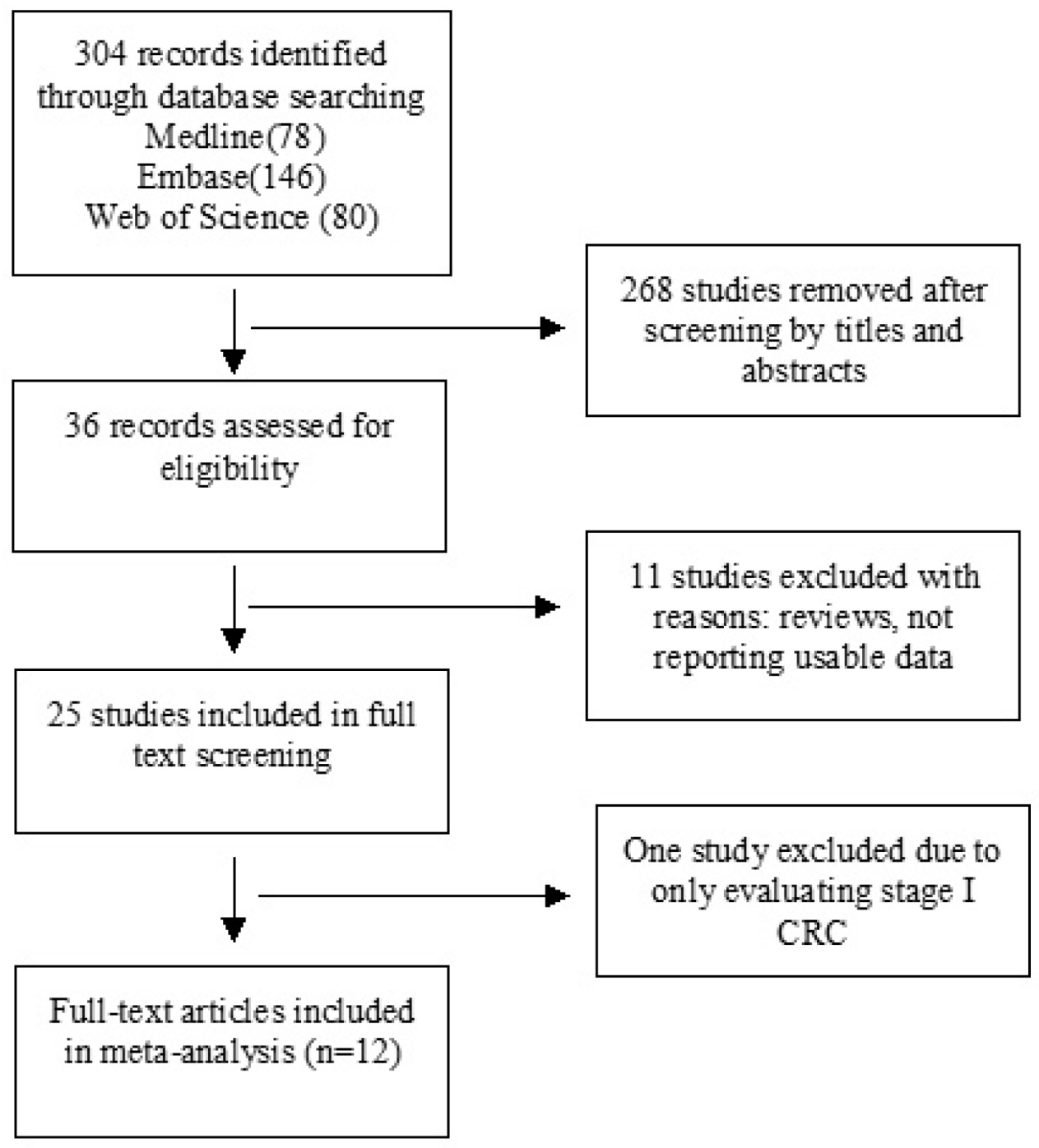

Figure 1: Schematic flow diagram for selection of included studies. 
Table 1: Main characteristics of included studies

\begin{tabular}{|c|c|c|c|c|c|c|c|c|c|c|c|c|c|c|}
\hline \multirow[t]{2}{*}{ Author } & \multirow[t]{2}{*}{ Year } & \multirow[t]{2}{*}{ Country } & \multirow[t]{2}{*}{ Methods } & \multicolumn{3}{|c|}{ Histology } & \multicolumn{2}{|c|}{ Tumor location } & \multicolumn{2}{|c|}{ Stage (TNM) } & \multicolumn{2}{|c|}{ Grade } & \multicolumn{2}{|c|}{$\begin{array}{c}\text { Smoking } \\
\text { status }\end{array}$} \\
\hline & & & & NCT & Ade & CRC & Proximal & Distal & $\mathbf{I}+\mathbf{I I}$ & III+IV & $\mathbf{L}$ & $\mathbf{H}$ & + & - \\
\hline Michailidi [33] & 2015 & Greece & MSP & $12 / 14$ & - & $18 / 61$ & - & - & - & - & - & - & - & - \\
\hline Samaei [34] & 2014 & Iran & MSP & $0 / 125$ & - & $44 / 125$ & $29 / 36$ & $18 / 50$ & $24 / 56$ & $22 / 69$ & $34 / 100$ & $10 / 25$ & - & - \\
\hline Dimberg [35] & 2013 & $\begin{array}{l}\text { Sweden/ } \\
\text { Vietnam }\end{array}$ & MSP & $66 / 101$ & - & $50 / 101$ & - & - & - & - & - & - & - & - \\
\hline Pack [36] & 2013 & Korea & MSP & $2 / 10$ & $6 / 10$ & - & - & - & - & - & - & - & - & - \\
\hline Qiu [37] & 2014 & China & MSP & $1 / 10$ & $45 / 67$ & $44 / 70$ & $21 / 35$ & $23 / 35$ & - & - & - & - & - & - \\
\hline Gay [38] & 2012 & UK & Pyrosequencing & - & - & - & $22 / 59$ & $48 / 112$ & $22 / 87$ & $14 / 69$ & $61 / 141$ & $6 / 25$ & - & - \\
\hline Kang [39] & 2012 & Korea & Q-MSP & $2 / 14$ & - & $52 / 100$ & - & - & $28 / 52$ & $24 / 48$ & - & - & $12 / 20$ & $40 / 80$ \\
\hline Leong [40] & 2011 & UK & Q-MSP & $1 / 19$ & & $22 / 51$ & & & & & & & - & - \\
\hline $\begin{array}{l}\text { Naghibalhossaini } \\
\text { [41] }\end{array}$ & 2011 & Iran & MSP & - & - & - & $30 / 30$ & $73 / 80$ & $66 / 71$ & $26 / 28$ & $48 / 49$ & $42 / 48$ & $53 / 56$ & $50 / 54$ \\
\hline Sameer [42] & 2011 & Kashmir & MSP & - & - & - & - & - & - & - & $9 / 38$ & $38 / 48$ & $33 / 55$ & $14 / 31$ \\
\hline Vasovcak [43] & 2011 & $\begin{array}{c}\text { Czech } \\
\text { Republic }\end{array}$ & MS-MLPA & - & - & - & $26 / 34$ & $45 / 60$ & $38 / 56$ & $30 / 44$ & - & - & - & - \\
\hline Belshaw [44] & 2010 & UK & Q-MSP & $2 / 8$ & - & $2 / 5$ & - & - & - & - & - & - & - & - \\
\hline $\operatorname{Kim}[45]$ & 2010 & Korea & Pyrosequencing & - & - & - & $9 / 68$ & $36 / 217$ & $28 / 169$ & $24 / 116$ & $40 / 253$ & $5 / 32$ & - & - \\
\hline Kamiyama [46] & 2009 & Japan & Q-MSP & - & - & - & $6 / 20$ & $10 / 25$ & - & - & - & - & - & - \\
\hline Derks [47] & 2006 & $\begin{array}{l}\text { European/ } \\
\text { USA }\end{array}$ & MSP & $3 / 18$ & $17 / 34$ & $10 / 18$ & & & - & - & - & - & - & - \\
\hline Iacopetta [27] & 2006 & Australia & Q-MSP & - & - & - & $24 / 90$ & $33 / 106$ & - & - & $41 / 122$ & $6 / 28$ & - & - \\
\hline Brandes [48] & 2005 & Netherlands & MSP & - & - & - & - & - & $19 / 30$ & $6 / 14$ & - & - & - & - \\
\hline Chen [49] & 2005 & Germany & MSP & $0 / 14$ & - & $17 / 34$ & - & - & - & - & - & - & - & - \\
\hline Ebert [50] & 2005 & Germany & MSP & $0 / 21$ & & $10 / 47$ & - & - & - & - & - & - & - & - \\
\hline $\operatorname{Kim}[51]$ & 2005 & Korea & MSP & $6 / 40$ & & $7 / 36$ & - & - & - & - & - & - & - & - \\
\hline Bai [52] & 2004 & China & MSP & $1 / 34$ & & $28 / 47$ & - & - & - & - & - & - & - & - \\
\hline Lee [53] & 2004 & Korea & MSP & $3 / 24$ & $34 / 95$ & $76 / 149$ & $29 / 56$ & $47 / 93$ & - & - & - & - & - & - \\
\hline Lind [54] & 2004 & Norway & MSP & - & - & - & $7 / 18$ & $13 / 37$ & $13 / 31$ & $8 / 26$ & $16 / 44$ & $4 / 11$ & - & - \\
\hline $\mathrm{Xu}$ [55] & 2004 & China & MSP & $0 / 6$ & $2 / 8$ & $5 / 65$ & - & - & - & - & - & - & - & - \\
\hline
\end{tabular}

MSP: methylation-specific PCR: MS-MLPA: methylation specific multiplex ligation-dependent probe amplification, NCT: normal control tissue; Ade: adenoma; CRC: colorectal carcinoma; L: low grade; H: high grade.

a demethylation agent [23]. In addition, Eads et al demonstrated that the expression of full-length Dnmt3bl enhanced the number of colon tumors in $A P C \mathrm{~min} /+$ mice by approximately twofold and increased the average size of colonic microadenomas $[24,25]$. Taken together, APC is a potential drug target for the development of personalized therapy in patients with $\mathrm{CRC}$; further investigation is required in future.

Among the included studies, the frequency of $A P C$ methylation have varied greatly from $17.9 \%$ to $62.8 \%$. This phenomenon maybe due to ethnic differences, different PCR primers used in the detection, as well as cancer heterogeneity. According to recent classification system, CRC is classified into two major groups: 1) hypermutated cancers with either microsatellite instability due to defective mismatch repair or ultramutated cancers with DNA polymerase epsilon proofreading mutations; 2) non-hypermutated, microsatellite stable cancers with a high frequency of DNA somatic copy number alterations, which showed common mutations in APC, TP53, KRAS, SMAD4 and PIK3CA. APC methylation is present more often in the first group of tumors with microsatellite-stable compared to the second group with microsatellite instability [26-29]. In addition, the $A P C$ methylation was inversely associated with TIMP3, TP53 and BRAF methylation [27]. Previous publications reported that $A P C$ was less frequently mutated alone, more commonly mutated with KRAS, TP53, PIK3CA and SMAD $[22,27]$, suggesting that the $A P C$ mutation occurs early in carcinogenesis, the alterations of other genes were involved during the transition from adenoma to carcinoma. $A P C$ methylation combined with the mutation of other genes could be a valuable biomarker for diagnosis and prognosis of CRC. Further study is necessary to substantiate this issue. 


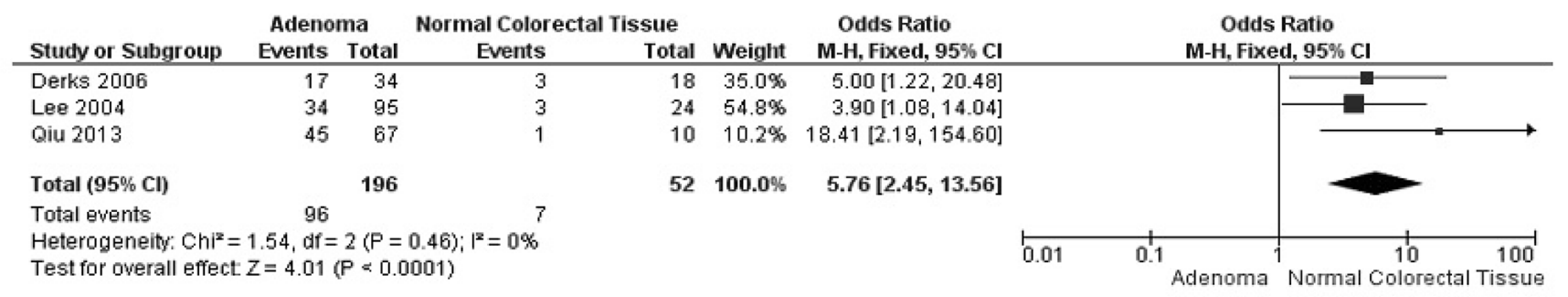

Figure 2: Forest plot for $A P C$ methylation in adenoma and normal colorectal tissue.

\begin{tabular}{|c|c|c|c|c|c|c|c|c|c|c|}
\hline \multirow[b]{2}{*}{ Study or Subgroup } & \multicolumn{2}{|c|}{ CRC Stage I } & \multicolumn{2}{|c|}{ Normal Colorectal Tissue } & \multirow[b]{2}{*}{ Weight } & \multirow{2}{*}{$\begin{array}{l}\text { Odds Ratio } \\
\text { M-H, Fixed, } 95 \% \mathrm{Cl}\end{array}$} & \multirow{2}{*}{\multicolumn{4}{|c|}{$\begin{array}{c}\text { Odds Ratio } \\
\text { M-H, Fixed, } 95 \% \mathrm{Cl}\end{array}$}} \\
\hline & Events & Total & Events & Total & & & & & & \\
\hline Kang 2012 & 2 & 3 & 2 & 14 & $17.8 \%$ & $12.00[0.71,203.14]$ & & & & \\
\hline Pack 2013 & 8 & 14 & 2 & 10 & $75.6 \%$ & $5.33[0.82,34.83]$ & & & & \\
\hline Samaei 2004 & 5 & 17 & 0 & 125 & $6.6 \%$ & $110.44[5.76,2116.07]$ & & & & + \\
\hline Total $(95 \% \mathrm{Cl})$ & & 34 & & 149 & $100.0 \%$ & $13.42[3.66,49.20]$ & & & & \\
\hline Total events & 15 & & -5 & & & & & & & \\
\hline $\begin{array}{l}\text { Heterogeneity: } \mathrm{Chi}^{2} \\
\text { Test for owerall effect }\end{array}$ & $\begin{array}{l}2.89, \mathrm{df}= \\
z=3.920\end{array}$ & $\begin{array}{l}2(P=0 \\
P<0.00\end{array}$ & $\begin{array}{l}0.24) ;\left.\right|^{z}=31 \% \\
001)\end{array}$ & & & & 0.01 & $\begin{array}{l}0.1 \\
\text { CRC stage I }\end{array}$ & Normal & $\begin{array}{cc}10 & 100 \\
\text { Colorectal Tissue }\end{array}$ \\
\hline
\end{tabular}

Figure 3: Forest plot for $A P C$ methylation in CRC stage I and normal colorectal tissue.

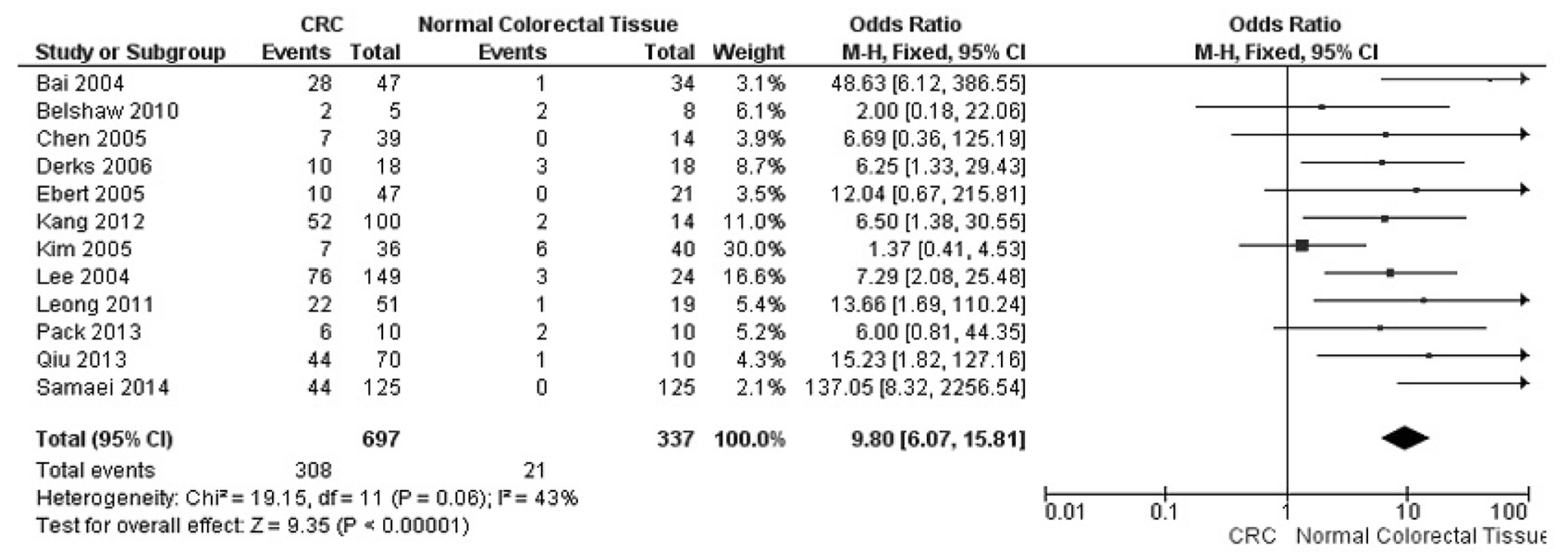

Figure 4: Forest plot for $A P C$ methylation in CRC and normal colorectal tissue.

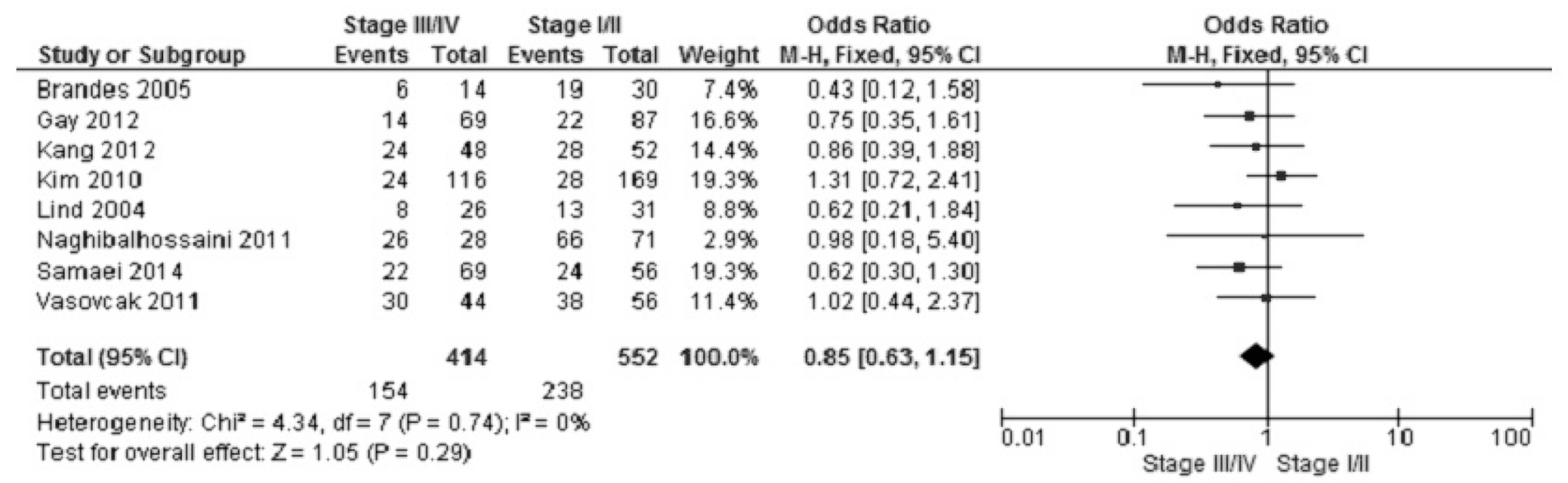

Figure 5: Forest plot for APC methylation in stage III/IV and stage I/II of CRC. 
We pooled seven studies and included 964 samples and analyzed the relationship of $A P C$ promoter methylation with the grade of CRC; the power was 0.89 , which indicated that $A P C$ promoter hypermethylation is not associated with grade. Furthermore, present analysis showed that $A P C$ promoter hypermethylation is not correlated with stages of $\mathrm{CRC}$, since the power of the study is small, further study with a larger number of samples is need to confirm this relationship.

Consistent results were shown in sensitivity analyses, indicating the stability of our analyses. All funnel plots did not show any obvious asymmetry, suggesting there is no publication bias in the meta-analysis. This study has several potential limitations. First, selection bias

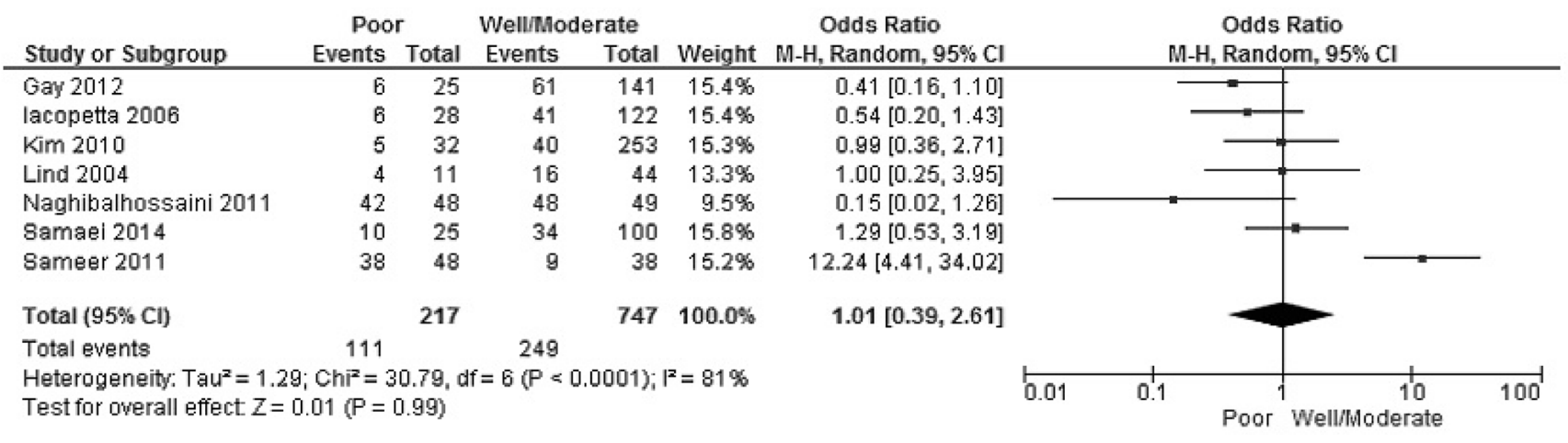

Figure 6: Forest plot for $A P C$ methylation in high grade and low grade of CRC.

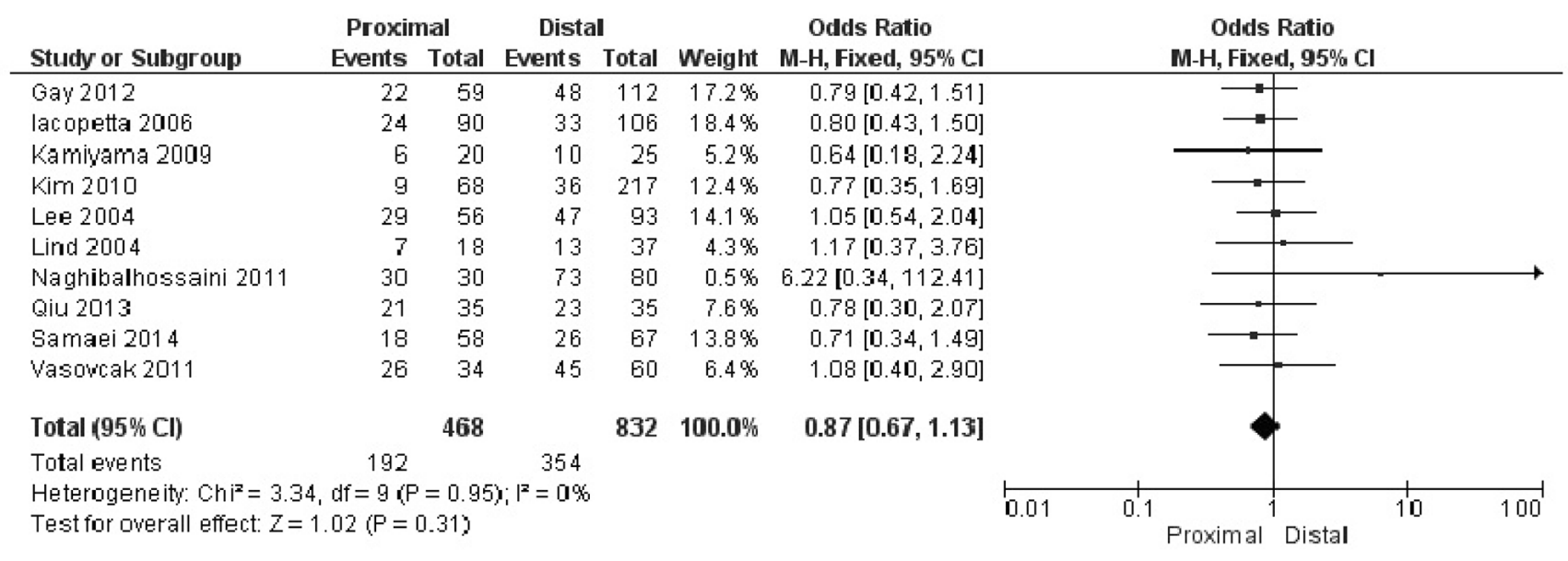

Figure 7: Forest plot for the correlation of $A P C$ hypermethylation and location of CRC.

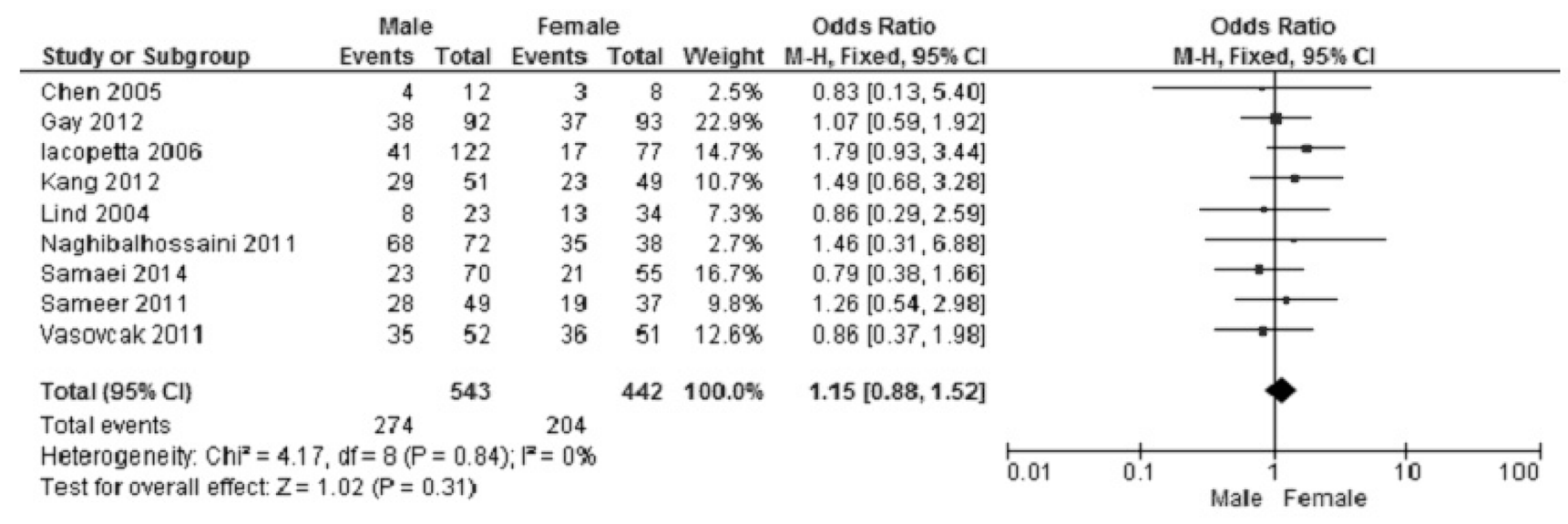

Figure 8: The frequency of $A P C$ hypermethylation was similar in male and female CRC patients. 
may exist since only publications in English and Chinese were included in the present study, which could affect the accuracy of results in certain extent. Caution should be taken when our findings are interpreted. Second, the possibility of information, selection biases and unidentified confounders could not be completely excluded because all of the included studies were observational. Third, our results showed that there is no significant correlation between $A P C$ methylation and gender, smoking behavior of CRC patients as well as tumor locations; since the power of the study is small, further evaluation with a larger number of samples is required in future.

In summary, our meta-analysis indicates that $A P C$ promoter hypermethylation is an early event of carcinogenesis of CRC, and $A P C$ methylation combined with the mutation of other genes could be a valuable biomarker for diagnosis and prognosis of CRC. APC promoter methylation is not significantly associated with overall survival in patients with CRC. APC is a potential drug target for development of personalized therapy.

\section{METHODS}

\section{Search strategy}

We performed this meta-analysis in accordance with the Preferred Reporting Items for Systematic Reviews and Meta-analysis (PRISMA) statement [30]. We searched the database of Medline, Web of science, and Embase up to July, 2016 without

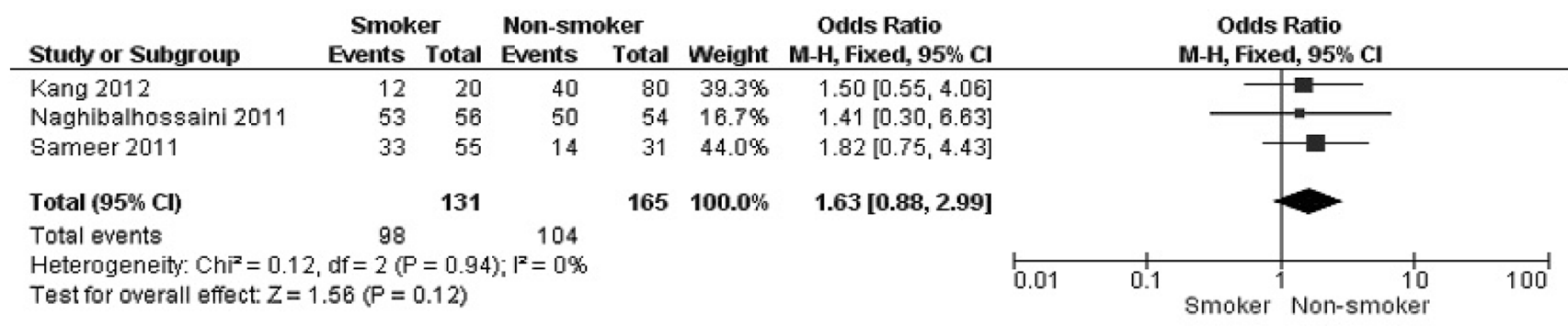

Figure 9: Plot for the relationship of $A P C$ hypermethylation and smoking status of patients with CRC.

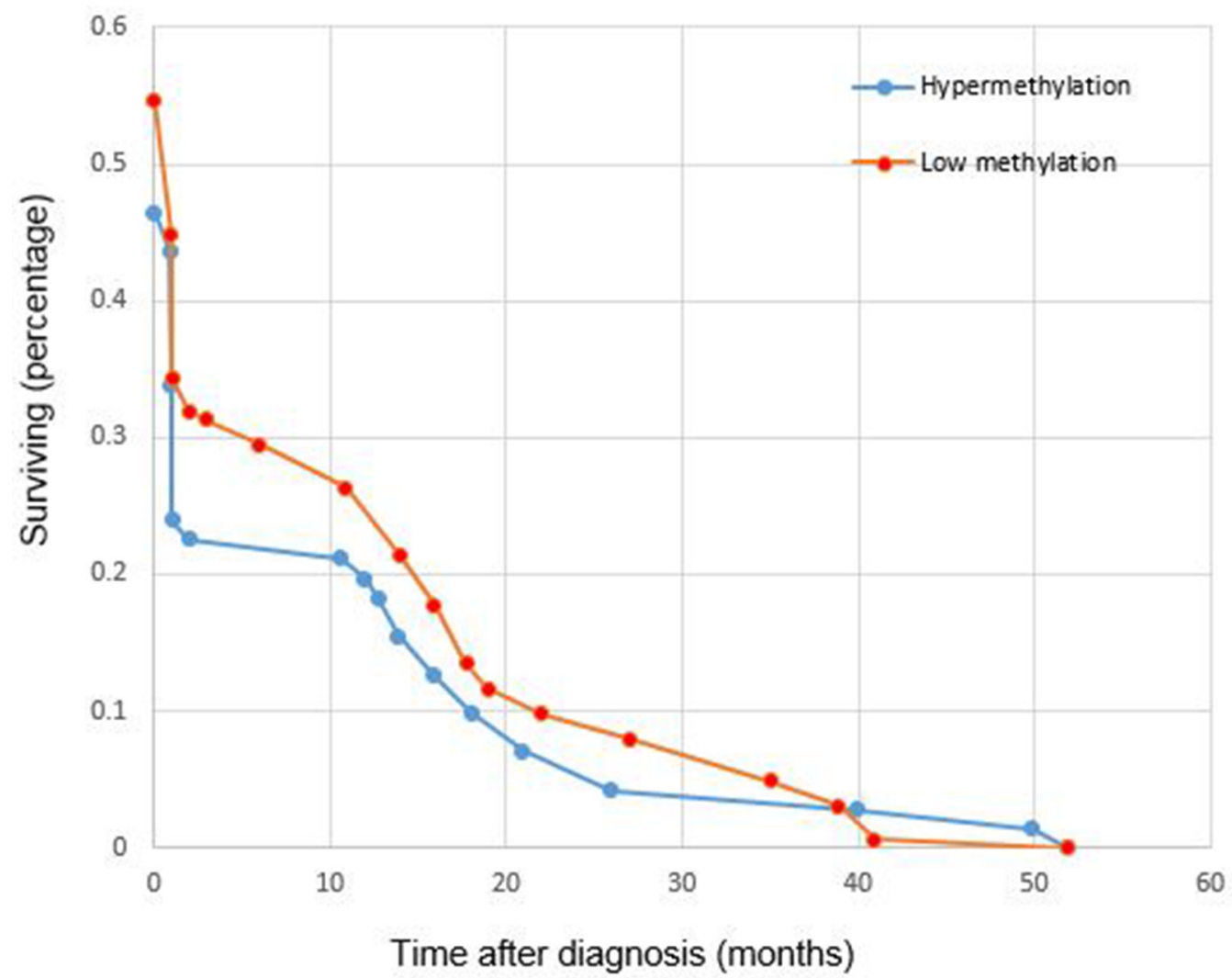

Figure 10: Plot for the overall survival of CRC patient with different $A P C$ promoter methylation status. Blue circles represent cases with $A P C$ hypermethylation, red circles represent cases with $A P C$ low methylation. Test p-value 0.5798 . 
A

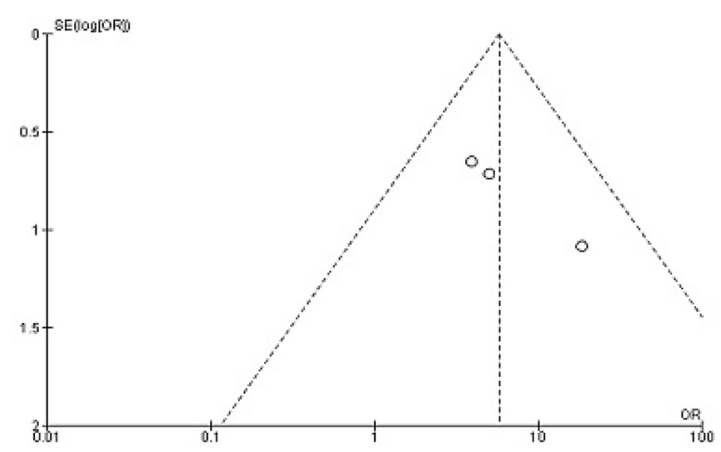

C

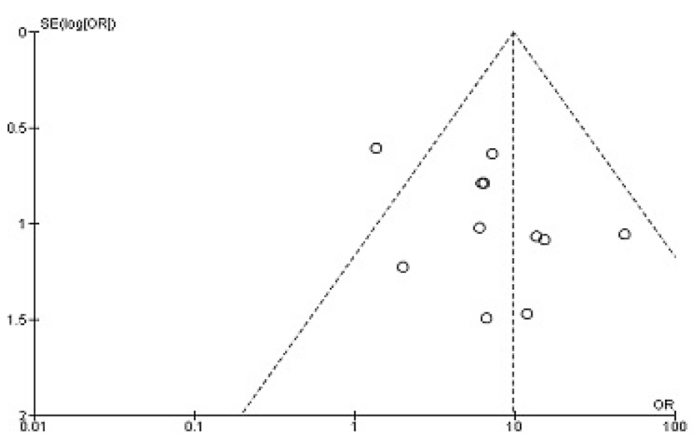

$\mathrm{E}$

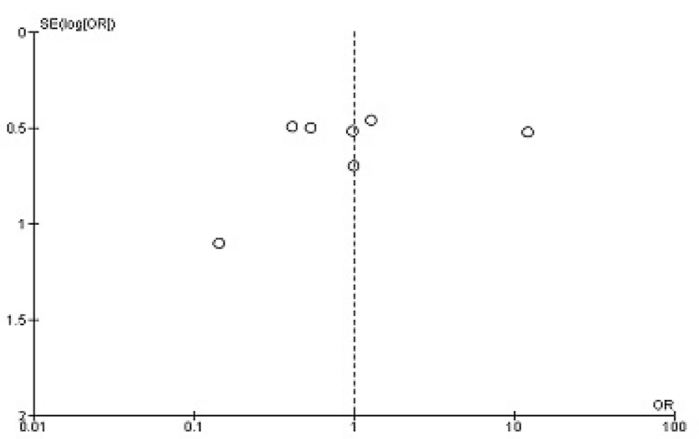

G

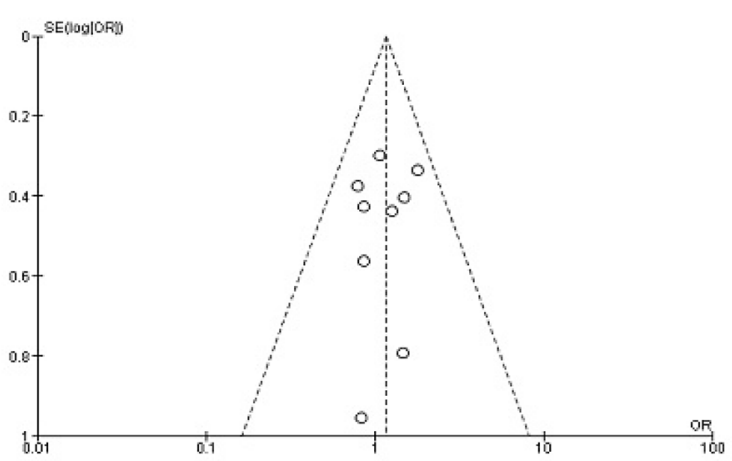

B

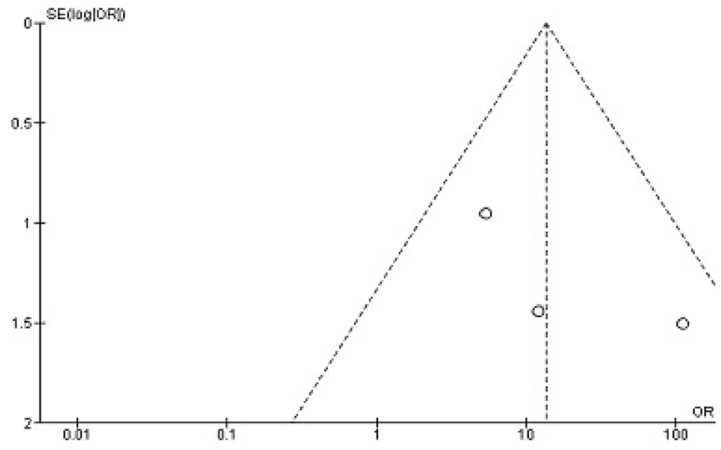

$\mathrm{D}$

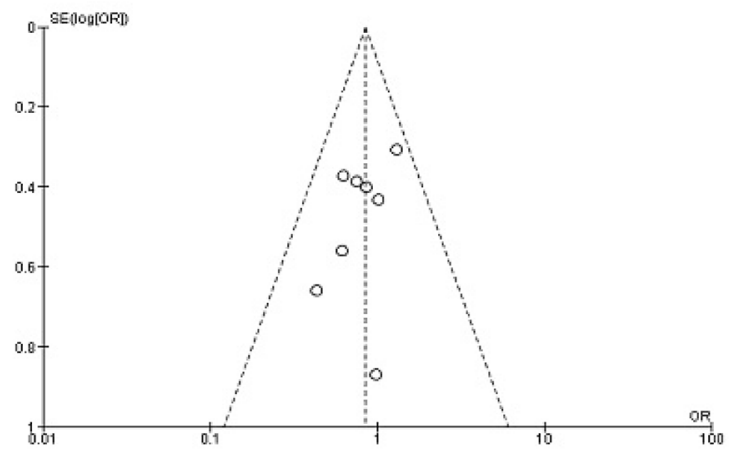

$\mathrm{F}$

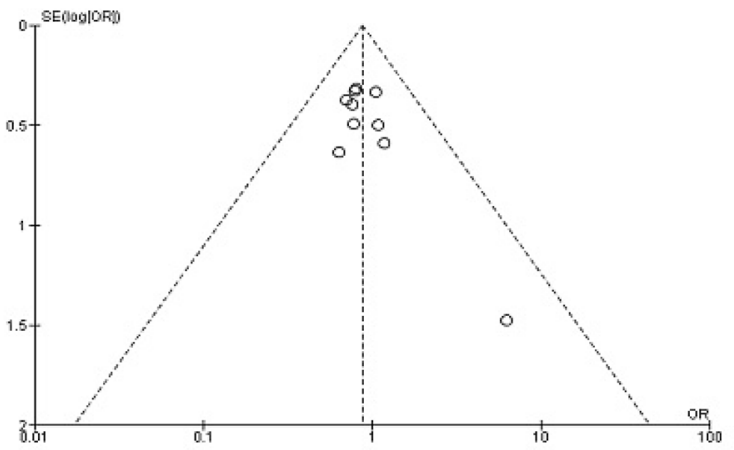

$\mathrm{H}$

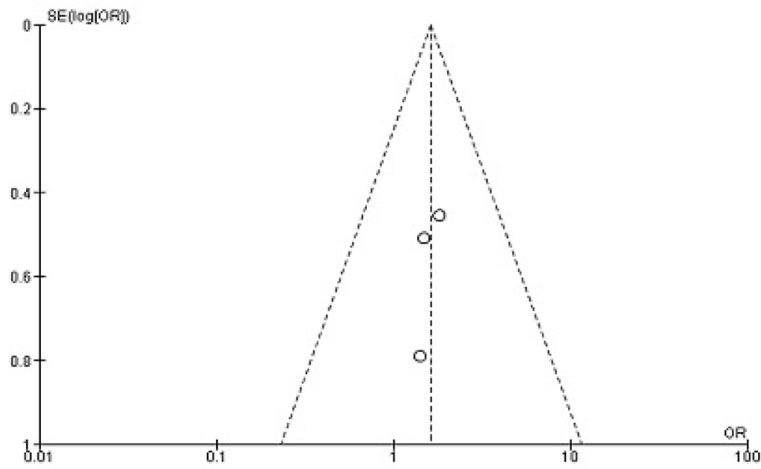

Figure 11: Funnel plot for publication bias. A. $A P C$ methylation in adenoma and normal colorectal tissue. B. $A P C$ methylation in CRC stage I and normal colorectal tissue. C. $A P C$ methylation in CRC and normal colorectal tissue. D. $A P C$ methylation in stage III/IV and stage I/II of CRC. E. $A P C$ methylation in high grade and low grade of CRC. F. The correlation of $A P C$ hypermethylation and location of CRC. G. $A P C$ hypermethylation in male and female CRC patients. H. The relationship of $A P C$ hypermethylation and smoking status of patients with CRC. S.E.: standard error; area of the circle represents the weight of individual study. 
language limitations. The following items were used for searching: APC, adenomatous polyposis coli, methylation, neoplasm, tumor, colorectal carcinoma, and CRC. A manual search using references from retrieved articles was performed for additional pertinent studies. We chose the most complete study to avoid duplication when the same populations were reported in several publications.

\section{Study selection}

Studies were included if they met the following inclusion criteria: 1) investigation $A P C$ methylation status and clinicopathological significance in CRC. 2) case-control, and cohort studies published as original studies. 3) studies that provided sufficient data to calculate ORs and 95\% confidence interval (CI).

Exclusion criteria were: 1) lack of sufficient data on $A P C$ methylation and clinicopathological features in $\mathrm{CRC}$, 2) reviews, case report, conference abstract and expert opinion and letters, 3) all publications regarding in vitro studies.

\section{Quality assessment}

The quality of each study was individually evaluated by each investigator utilizing Newcastle-Ottawa quality assessment scale [31]. All observational studies were considered moderate to high quality, with median Newcastle-Ottawa quality assessment scale of 7 (range, 6-9) (data not shown).

\section{Data extraction}

A standardized data extraction form was used. Eligible studies were reviewed and the following data were extracted: (1) first author's name, (2) year of study, (3) study location, (4) methylation detect methods, (5) sample size, (5) tumor location, cancer TMN stages and grade (6) gender and smoking status of participants.

\section{Survival analysis with TCGA data}

Overall survival was analyzed by selecting Colorectal Adenocarcinoma (TCGA, Nature 2012) and gene $A P C$ via cBioPortal for provisional data. $A P C$ methylation and overall survival data were downloaded. Hypermethylation and Low methylation were sorted out according to methylation beta-value. If the methylation beta-value was more than 0.3 , the case was considered as hypermethylation, if the methylation beta-value was less than 0.3 , the case was considered as low methylation. The overall survival was plotted on 236 cases (methylation HM27) which included 72 cases with $A P C$ hypermethylation (methylation betavalue was more than 0.3 ) and 164 cases with $A P C$ low methylation (methylation beta-value was less than 0.3 ) with Excel 2013.

\section{Statistical analysis}

Review Manage 5.3 from the Cochrane Collaboration was used for data analysis. Odds Ratio with 95\% confidence intervals (CIs). This statistic was complemented with the $I^{2}$ statistic, which quantifies the proportion of the cumulative variation across studies that is due to heterogeneity rather than chance. When heterogeneity was not an issue $\left(I^{2}\right.$ values $\left.<50 \%\right)$, a fixed effect model was used to calculate parameters. When there was substantial heterogeneity ( $I^{2}$ values $\geq 50 \%$ ), a randomeffects model was used to pool data and attempt to identify potential sources of heterogeneity based on subgroup analyses. Two sided statistical tests and p-value were used.

\section{Evaluation for publication bias}

The presence of publication bias was assessed by funnel plots of logarithm of odds ratios versus their standard errors [32].

\section{Author contributions}

TL, HW, YZ, and YC contributed substantially to the study and design, collection of data, and analysis of data. YZ, XW, and XZ contributed substantially to the acquisition, analysis, interpretation of data and performed the statistical analysis. TL and SD have been involved in the drafting and revision of the article. SD has full access to all data and the final responsibility for the decision to submit the article for publication. All authors read and approved the final manuscript.

\section{ACKNOWLEDGMENTS}

This work is supported by the Key research and development program of Shandong Province, 2016GSF201018 (TL). The funding institution does not have any roles in the study design, data collection, or analysis.

\section{CONFLICTS OF INTEREST}

The authors declare that they have no conflicts of interest.

\section{REFERENCES}

1. Carmona FJ, Esteller M. Epigenomics of human colon cancer. Mutat Res. 2010; 693:53-60.

2. Venkatachalam R, Ligtenberg MJ, Hoogerbrugge N, de Bruijn DR, Kuiper RP, Geurts van Kessel A. The epigenetics 
of (hereditary) colorectal cancer. Cancer Genet Cytogenet. 2010; 203:1-6.

3. Kinzler KW, Nilbert MC, Su LK, Vogelstein B, Bryan TM, Levy DB, Smith KJ, Preisinger AC, Hedge P, McKechnie D, Finniear R, Markham A, Groffen J, et al. Identification of FAP locus genes from chromosome 5q21. Science. 1991; 253:661-665.

4. Nishisho I, Nakamura Y, Miyoshi Y, Miki Y, Ando H, Horii A, Koyama K, Utsunomiya J, Baba S, Hedge P. Mutations of chromosome 5q21 genes in FAP and colorectal cancer patients. Science. 1991; 253:665-669.

5. Joslyn G, Carlson M, Thliveris A, Albertsen H, Gelbert L, Samowitz W, Groden J, Stevens J, Spirio L, Robertson M, Sargeant L, Krapcho K, Wolff E, et al. Identification of deletion mutations and three new genes at the familial polyposis locus. Cell. 1991; 66:601-613.

6. Groden J, Thliveris A, Samowitz W, Carlson M, Gelbert L, Albertsen H, Joslyn G, Stevens J, Spirio L, Robertson M, Sargeant L, Krapcho K, Wolff E, et al. Identification and characterization of the familial adenomatous polyposis coli gene. Cell. 1991; 66:589-600.

7. Cole AM, Myant K, Reed KR, Ridgway RA, Athineos D, Van den Brink GR, Muncan V, Clevers H, Clarke AR, Sicinski P and Sansom OJ. Cyclin D2-cyclin-dependent kinase $4 / 6$ is required for efficient proliferation and tumorigenesis following Apc loss. Cancer Res. 2010; 70:8149-8158.

8. Panarelli NC, Vaughn CP, Samowitz WS, Yantiss RK. Sporadic microsatellite instability-high colon cancers rarely display immunohistochemical evidence of Wnt signaling activation. Am J Surg Pathol. 2015; 39:313-317.

9. Brock MV, Hooker CM, Ota-Machida E, Han Y, Guo M, Ames S, Glockner S, Piantadosi S, Gabrielson E, Pridham G, Pelosky K, Belinsky SA, Yang SC, et al. DNA methylation markers and early recurrence in stage I lung cancer. N Engl J Med. 2008; 358:1118-1128.

10. Cancer Genome Atlas Network. Comprehensive molecular characterization of human colon and rectal cancer. Nature. 2012; 487:330-337.

11. Hamilton SR. The molecular genetics of colorectal neoplasia. Gastroenterology. 1993; 105:3-7.

12. Irby RB, Mao W, Coppola D, Kang J, Loubeau JM, Trudeau W, Karl R, Fujita DJ, Jove R, Yeatman TJ. Activating SRC mutation in a subset of advanced human colon cancers. Nat Genet. 1999; 21:187-190.

13. Tahara E. Genetic alterations in human gastrointestinal cancers. The application to molecular diagnosis. Cancer. $1995 ; 75: 1410-1417$.

14. Thiagalingam S, Lengauer C, Leach FS, Schutte M, Hahn SA, Overhauser J, Willson JK, Markowitz S, Hamilton SR, Kern SE, Kinzler KW, Vogelstein B. Evaluation of candidate tumour suppressor genes on chromosome 18 in colorectal cancers. Nat Genet. 1996; 13:343-346.
15. Fearon ER. Molecular genetics of colorectal cancer. Annu Rev Pathol. 2011; 6:479-507.

16. Jen J, Powell SM, Papadopoulos N, Smith KJ, Hamilton SR, Vogelstein B, Kinzler KW. Molecular determinants of dysplasia in colorectal lesions. Cancer Res. 1994; 54:5523-5526.

17. Kinzler KW, Vogelstein B. Lessons from hereditary colorectal cancer. Cell. 1996; 87:159-170.

18. Levy DB, Smith KJ, Beazer-Barclay Y, Hamilton SR, Vogelstein B, Kinzler KW. Inactivation of both APC alleles in human and mouse tumors. Cancer Res. 1994; 54:5953-5958.

19. Smith AJ, Stern HS, Penner M, Hay K, Mitri A, Bapat BV and Gallinger S. Somatic APC and K-ras codon 12 mutations in aberrant crypt foci from human colons. Cancer Res. 1994; 54:5527-5530.

20. Haggar FA, Boushey RP. Colorectal cancer epidemiology: incidence, mortality, survival, and risk factors. Clin Colon Rectal Surg. 2009; 22:191-197.

21. Ding Z, Jiang T, Piao Y, Han T, Han Y, Xie X. Meta-analysis of the association between APC promoter methylation and colorectal cancer. Onco Targets Ther. 2015; 8:211-222.

22. Schell MJ, Yang M, Teer JK, Lo FY, Madan A, Coppola D, Monteiro AN, Nebozhyn MV, Yue B, Loboda A, BienWillner GA, Greenawalt DM, Yeatman TJ. A multigene mutation classification of 468 colorectal cancers reveals a prognostic role for APC. Nat Commun. 2016; 7:11743.

23. Eads CA, Nickel AE, Laird PW. Complete genetic suppression of polyp formation and reduction of CpGisland hypermethylation in $A p c^{(\mathrm{Min} /+)} \mathrm{Dnmt1-hypomorphic}$ mice. Cancer Res. 2002; 62:1296-1299.

24. Eads CA, Lord RV, Kurumboor SK, Wickramasinghe K, Skinner ML, Long TI, Peters JH, DeMeester TR, Danenberg KD, Danenberg PV, Laird PW, Skinner KA. Fields of aberrant $\mathrm{CpG}$ island hypermethylation in Barrett's esophagus and associated adenocarcinoma. Cancer Res. 2000; 60:5021-5026.

25. Linhart HG, Lin H, Yamada Y, Moran E, Steine EJ, Gokhale S, Lo G, Cantu E, Ehrich M, He T, Meissner A, Jaenisch R. Dnmt3b promotes tumorigenesis in vivo by gene-specific de novo methylation and transcriptional silencing. Genes Dev. 2007; 21:3110-3122.

26. Derks S, Postma C, Carvalho B, van den Bosch SM, Moerkerk PT, Herman JG, Weijenberg MP, de Bruine AP, Meijer GA, van Engeland M. Integrated analysis of chromosomal, microsatellite and epigenetic instability in colorectal cancer identifies specific associations between promoter methylation of pivotal tumour suppressor and DNA repair genes and specific chromosomal alterations. Carcinogenesis. 2008; 29:434-439.

27. Iacopetta B, Grieu F, Li W, Ruszkiewicz A, Caruso M, Moore J, Watanabe G, Kawakami K. APC gene methylation is inversely correlated with features of the $\mathrm{CpG}$ island 
methylator phenotype in colorectal cancer. Int J Cancer. 2006; 119:2272-2278.

28. Thorstensen L, Lind GE, Lovig T, Diep CB, Meling GI, Rognum TO, Lothe RA. Genetic and epigenetic changes of components affecting the WNT pathway in colorectal carcinomas stratified by microsatellite instability. Neoplasia. 2005; 7:99-108.

29. Muller MF, Ibrahim AE, Arends MJ. Molecular pathological classification of colorectal cancer. Virchows Arch. 2016; 469:125-134.

30. Moher D, Liberati A, Tetzlaff J, Altman DG, Group P. Preferred reporting items for systematic reviews and meta-analyses: the PRISMA statement. PLoS Med. 2009; 6:e1000097.

31. Stang A. Critical evaluation of the Newcastle-Ottawa scale for the assessment of the quality of nonrandomized studies in meta-analyses. Eur J Epidemiol. 2010; 25:603-605.

32. Easterbrook PJ, Berlin JA, Gopalan R, Matthews DR. Publication bias in clinical research. Lancet. 1991; 337:867-872.

33. Michailidi C, Theocharis S, Tsourouflis G, Pletsa V, Kouraklis G, Patsouris E, Papavassiliou AG, Troungos C. Expression and promoter methylation status of hMLH1, MGMT, APC, and CDH1 genes in patients with colon adenocarcinoma. Exp Biol Med (Maywood). 2015; 240:1599-1605.

34. Samaei NM, Yazdani Y, Alizadeh-Navaei R, Azadeh H, Farazmandfar T. Promoter methylation analysis of WNT/ beta-catenin pathway regulators and its association with expression of DNMT1 enzyme in colorectal cancer. J Biomed Sci. 2014; 21:73.

35. Dimberg J, Hong TT, Skarstedt M, Lofgren S, Zar N, Matussek A. Analysis of APC and IGFBP7 promoter gene methylation in Swedish and Vietnamese colorectal cancer patients. Oncol Lett. 2013; 5:25-30.

36. Pack SC, Kim HR, Lim SW, Kim HY, Ko JY, Lee KS, Hwang D, Park SI, Kang H, Park SW, Hong GY, Hwang SM, Shin MG, Lee S. Usefulness of plasma epigenetic changes of five major genes involved in the pathogenesis of colorectal cancer. Int J Colorectal Dis. 2013; 28:139-147.

37. Qiu Y, Fu X, Zhang W, Xu Y, Xiao L, Chen X, Shi L, Zhou X, Xia G, Peng Y, Deng M. Prevalence and molecular characterisation of the sessile serrated adenoma in a subset of the Chinese population. J Clin Pathol. 2014; 67:491-498.

38. Gay LJ, Mitrou PN, Keen J, Bowman R, Naguib A, Cooke J, Kuhnle GG, Burns PA, Luben R, Lentjes M, Khaw KT, Ball RY, Ibrahim AE, Arends MJ. Dietary, lifestyle and clinicopathological factors associated with APC mutations and promoter methylation in colorectal cancers from the EPIC-Norfolk study. J Pathol. 2012; 228:405-415.

39. Kang HJ, Kim EJ, Kim BG, You CH, Lee SY, Kim DI, Hong YS. Quantitative analysis of cancer-associated gene methylation connected to risk factors in Korean colorectal cancer patients. J Prev Med Public Health. 2012; 45:251-258.
40. Leong KJ, Wei W, Tannahill LA, Caldwell GM, Jones CE, Morton DG, Matthews GM, Bach SP. Methylation profiling of rectal cancer identifies novel markers of early-stage disease. Br J Surg. 2011; 98:724-734.

41. Naghibalhossaini F, Hosseini HM, Mokarram P, Zamani M. High frequency of genes' promoter methylation, but lack of BRAF V600E mutation among Iranian colorectal cancer patients. Pathol Oncol Res. 2011; 17:819-825.

42. Syed Sameer A, Shah ZA, Abdullah S, Chowdri NA, Siddiqi MA. Analysis of molecular aberrations of Wnt pathway gladiators in colorectal cancer in the Kashmiri population. Hum Genomics. 2011; 5:441-452.

43. Vasovcak P, Pavlikova K, Sedlacek Z, Skapa P, Kouda M, Hoch J, Krepelova A. Molecular genetic analysis of 103 sporadic colorectal tumours in Czech patients. PLoS One. 2011; 6:e24114.

44. Belshaw NJ, Pal N, Tapp HS, Dainty JR, Lewis MP, Williams MR, Lund EK, Johnson IT. Patterns of DNA methylation in individual colonic crypts reveal aging and cancer-related field defects in the morphologically normal mucosa. Carcinogenesis. 2010; 31:1158-1163.

45. Kim JC, Choi JS, Roh SA, Cho DH, Kim TW, Kim YS. Promoter methylation of specific genes is associated with the phenotype and progression of colorectal adenocarcinomas. Ann Surg Oncol. 2010; 17:1767-1776.

46. Kamiyama H, Noda H, Takata O, Suzuki K, Kawamura Y. Konishi F. Promoter hypermethylation of tumor-related genes in peritoneal lavage and the prognosis of patients with colorectal cancer. J Surg Oncol. 2009; 100:69-74.

47. Derks S, Postma C, Moerkerk PT, van den Bosch SM, Carvalho B, Hermsen MA, Giaretti W, Herman JG, Weijenberg MP, de Bruine AP, Meijer GA, van Engeland M. Promoter methylation precedes chromosomal alterations in colorectal cancer development. Cell Oncol. 2006; 28:247-257.

48. Brandes JC, van Engeland M, Wouters KA, Weijenberg MP, Herman JG. CHFR promoter hypermethylation in colon cancer correlates with the microsatellite instability phenotype. Carcinogenesis. 2005; 26:1152-1156.

49. Chen J, Rocken C, Lofton-Day C, Schulz HU, Muller O, Kutzner N, Malfertheiner P, Ebert MP. Molecular analysis of APC promoter methylation and protein expression in colorectal cancer metastasis. Carcinogenesis. 2005; 26:37-43.

50. Ebert MP, Mooney SH, Tonnes-Priddy L, Lograsso J, Hoffmann J, Chen J, Rocken C, Schulz HU, Malfertheiner P, Lofton-Day C. Hypermethylation of the TPEF/HPP1 gene in primary and metastatic colorectal cancers. Neoplasia. 2005; 7:771-778.

51. Kim HC, Roh SA, Ga IH, Kim JS, Yu CS, Kim JC. CpG island methylation as an early event during adenoma progression in carcinogenesis of sporadic colorectal cancer. J Gastroenterol Hepatol. 2005; 20:1920-1926.

52. Bai AH, Tong JH, To KF, Chan MW, Man EP, Lo KW, Lee JF, Sung JJ, Leung WK. Promoter hypermethylation 
of tumor-related genes in the progression of colorectal neoplasia. Int J Cancer. 2004; 112:846-853.

53. Lee S, Hwang KS, Lee HJ, Kim JS, Kang GH. Aberrant $\mathrm{CpG}$ island hypermethylation of multiple genes in colorectal neoplasia. Lab Invest. 2004; 84:884-893.

54. Lind GE, Thorstensen L, Lovig T, Meling GI, Hamelin R, Rognum TO, Esteller M, Lothe RA. A CpG island hypermethylation profile of primary colorectal carcinomas and colon cancer cell lines. Mol Cancer. 2004; 3:28.

55. Xu XL, Yu J, Zhang HY, Sun MH, Gu J, Du X, Shi DR, Wang P, Yang ZH, Zhu JD. Methylation profile of the promoter $\mathrm{CpG}$ islands of 31 genes that may contribute to colorectal carcinogenesis. World J Gastroenterol. 2004; 10:3441-3454. 